\title{
Residual Effects of Diuron [3-(3,4-Dichlorophenyl)- 1,1-Dimethylurea] on the Sugar Content and Sugar- Metabolizing Enzymes of Ratoon Sugarcane 25 Months Following Different Soil Treatment
}

\author{
Alex G. Alexander and Jaime González Ibáñez
}

\section{INTRODUCTION}

The substituted urea herbicides ${ }^{2}$ have found widespread use in agriculture because of their long-term persistence in the soil and lethal action against a wide range of plants (29, p. 19) ${ }^{3}$. According to Crafts ( 7, p. 99), Monuron has been recommended for use in sugarcane in Hawaii, Louisiana, and Florida, while sugarcane has in recent years been added to the list of crops in which Diuron can be used safely. In Puerto Rico, Diuron has generally replaced Monuron as the primary herbicide employed with sugarcane. In 1963 an estimated minimum of 250,000 pounds was applied to Puerto Rican cane fields. At Central Aguirre alone some 50,000 pounds were applied during the past yeart.

Investigations concerning the mode of action of the urea herbicides have repeatedly emphasized the curtailment of photosynthesis. Low concentrations of Monuron inhibit the Hill reaction (5,13,30). Moreland et al. (16) reported that the Hill reaction was more effectively curtailed by Diuron than by any other of a series of tested herbicides.

The possibility that an essential catalyst in photoreduction is blocked by substituted ureas was pointed out by the work of Bishop (2) and by Todd and coworkers ( 7, p. 99). Bishop found that photoreduction was not inhibited by Diuron in Mn-deficient A. braunii, and that under a condition of $\mathrm{Mn}^{2+}$ deficiency, a catalyst active both in the pathways to oxygen and dehydrogenase can be reduced and thus become available for photoreduction. According to Crafts ( 7, pp. 99-102) a series of experiments by Todd and coworkers with Euglena, Chlorella, and the photosynthetic bacterium R. rubrum showed that light and $\mathrm{CO}_{2}$ are required for Monuron to exert its toxic action. They concluded that a growth-inhibiting substance is formed in response to Monuron, and that this happens early in the photo-

1 Associate Plant Physiologist and Assistant Biochemist, respectively, Agricultural Experiment Station, University of Puerto Rico, Río Piedras, P.R.

2 The term "substituted ureas" refers herein to the closely related compounds Fenuron, Monuron, Diuron, and Neburon.

3 Italic numbers in parentheses refer to Literature Cited, pp. 301-3.

- Personal communication with M. Mejia, Sales Representative of Karmex DW, Rio Piedras, P.R. 
synthetic process when light is being converted to excitation energy and subsequently to the chemical energy need for photosynthesis. After further work with xanthium, Euglena and Chlorella, Todd's associates concluded that the Monuron action occurs close to the site of light absorption, and FMN (flavin mononucleotide) was suggested as the likely intermediate upon which Monuron acts. It was found that when photoactivated by blue light, one molecule of FMN will counteract one molecule of Monuron. An FMN-Monuron complex formed in vitro in the presence of light did not inhibit photosynthesis.

There is also evidence that phosphate and sugar metabolism is involved in the action of Monuron. Tomizawa (26) reported that Monuron increased the uptake of $\mathrm{P}^{32}$ by soybeans and that inorganic phosphorus increased in all parts of the plant. However, the incorporation of phosphorus into 3phosphoglyceric acid and sugar intermediates of the glycolytic pathway was decreased. Jagendorf (13) found that Monuron inhibits the formation of ATP (adenosinetriphosphate) from $\Lambda \mathrm{DP}$ (adenosinediphosphate) and inorganic phosphorus. Hilton (12) observed that carbohydrates were effective in reversing the herbicidal action of substituted ureas. Gentner and Hilton (9) reported that barley plants treated at the leaf tips with sucrose were partly protected from the action of these herbicides. Geoghegan's respiratory studies with $C$. vulgaris, employing low concentrations of glucose, fructose, glucose-1-phosphate, and a series of organic acids, revealed that respiration was stimulated by Monuron (8). Both Monuron and DNP (dinitrophenol) inhibited respiration of Chlorella with glucose concentrations of $\mathrm{M} 300^{5}$ and above, and Geoghegan concluded that these compounds inhibited an enzyme system coupling glucose oxidation with glucose assimilation.

Although considerable progress has been made toward clarifying the mode of lethal action of the substituted ureas, very little fundamental work has been done regarding the effects of these compounds upon the economic crops they serve. In Puerto Rico there is a dearth of information concerning the physiological effects of Diuron upon sugarcane. This problem is intensified in sugar-producing areas where much depends upon the stand, vigor, and sugar-producing capability of the ratoon crops. The investigations reported herein were concerned with residual effects of Diuron upon the sugar-metabolizing systems of ratoon sugarcane which had been grown on field plots treated with Diuron 25 months previously.

\section{MATERIALS AND ME'THODS}

Two sets of samples were taken from 5- to 6-month-old ratoon sugarcane, of the variety P.R. 1013, which had been grown on a Mabi clay soil

${ }^{5} \mathrm{M}=$ "molar." 
at the Gurabo Substation under the direction of Dr. Héctor R. Cibes, Plant Physiologist ${ }^{6}$.

The first set of samples, consisting of leaf and sheath tissues for enzyme and sugar analyses, was harvested on September 4, 1963. Three representative canes were selected from each replicate. The basal 14 to 18 inches of leaves +1 to $+4^{7}$ were trimmed with scissors, inserted in $200 \times 38-\mathrm{mm}$. pyrex culture tubes, and frozen immediately in a mixture of Dry Ice (solid carbon dioxide) and acetone. The frozen tissues were stored at $-20^{\circ} \mathrm{C}$. and subsequently removed to a cold room where they were dried under vaccum, at $0-2^{\circ} \mathrm{C}$., with the aid of a Virtis Roto-Freeze drying assembly. When thoroughly dry the leaves were ground in the cold with a Wiley Mill to pass a 60 -mesh screen, sealed with plastic tape in sample jars equipped with screw tops, and stored at $0-2^{\circ} \mathrm{C}$. until extractions could be made at our convenience. Sheath tissues were trimmed with scissors and dried in a forced-air oven. These were also ground with a Wiley Mill to pass a 60 -mesh screen prior to making extractions.

The second set of samples was taken Octoher 10,1963, and was composed of millable cane. Ten representative canes were harvested from cach plot.

- The original seed-pieces were planted Aug. 25, 1961, in a series of experimental plots of 400 square feet each. Precmergence herbicides in water solution were applied to the plot surfaces on August 31 with the aid of a knapsack sprayer equipped with No. 8004 nozzle tips. The following treatments were applied: Monuron, Diuron, Simazine, and Atrazine at rates of 2,4 , and 8 pounds per acre; Fenac at 3,4 , and 8 pounds per acre; and an untreated control. The experimental design was a partly balanced incomplete block with 6 replicates for cach of the 16 treatments.

Data on weight of weeds were recorded on Nov, 22, 1961. This was accomplished without disturbing the soil in any of the experimental plots. The first cane harvest was made Apr. 11, 1963, when the eane was about 20 months of age. No significant differences were found between treatments with regard to tons of cane per acre or sucrose-percent-cane.

That the Jiuron treatments had indeed uffected the cane plants was realized by one of the authors when he visited the plots about 4 months after the original cane had been harvested. The ratoon crop was noticeably sparse among Diuron-treated plots, appearing to represent about a 50-percent stand. There was a general stunting of the young canc. Many plants exhibited a sepia mottling of the leaf tips, although the tissues were still alive. A yellowing of the foliage appeared sporadically among the Diuron-treated plots. A month later the stand of cane was still sparse, but the Diuron-treated plants had recovered most of their vigor. A preliminary set of sheath samples was taken at this time for sugar analyses at the Main Station. The analyses revealed some striking variations in the sucrose, total reducing sugar, and glucose fractions. The decision was then made to investigate more thoroughly some of the effects being exerted by the Diuron treatments upon the sugar-metabolizing systems of the young cane.

7 The leaf nomenelature used here is that of Kuijper (14), in which the uppermost leaf bearing a visible dewlap is designated +1 . 
These were ground with a laboratory mill at Río Piedras and estimations were made of percentage sucrose in juice and in cane.

Sheath and leaf sugars were measured with distilled-water extracts of the dried tissues. Total ketoses were determined by the resorcinol technique of Roe (19), and total reducing sugars were measured by the dinitrosalicylic acid method of Sumner (24). Sucrose was distinguished from fructose according to the method of Cardini et al. (4), which destroys fructose by heating the samples for 10 minutes at $100^{\circ} \mathrm{C}$. in $0.25 \mathrm{~N} \mathrm{NaOH}$. This procedure is specific for reducing sugars and it enabled us to measure the nonsugar-reducing power of the samples. Glucose was estimated by subtracting the fructose values from the corrected total reducing-sugar fraction.

Enzyme protein was extracted from leaf samples with water and precipitated with ammonium sulfate. From each sample, $6 \mathrm{gm}$. of the powdered, freeze-dried leaf tissue were placed in a stoppered $125 \mathrm{ml}$. Erlenmeyer flask containing $100 \mathrm{ml}$. of distilled water and the mixture was shaken mechanically for 1 hour. Most of the tissue debris was removed by expressing the material through four layers of No. 10 Curity absorbent gauze. The suspension was chilled to $1^{\circ} \mathrm{C}$. and centrifuged at 3,500 r.p.m. for $20 \mathrm{~min}-$ utes. A clear, amber supernatant liquid was obtained from which aliquots were drawn and diluted for sugar analysis. The extracts were brought to $100 \mathrm{ml}$. volume and, after adjusting the $\mathrm{pH}$ to 7.0 with $0.2 \mathrm{~N} \mathrm{NaOH}$, sufficient ammonium sulfate was added to bring the solutions to 95-percent saturation. The salt was added slowly over a period of about 40 minutes while the samples were constantly agitated with the aid of magnetic stirrers. Protein began to precipitate at 32-percent saturation and, after all the salt was added, the solutions were allowed to stand at $4^{\circ} \mathrm{C}$. for 6 hours to increase protein yield.

The precipitate-containing solutions were centrifuged at 3,500 r.p.m. for 10 minutes and the supernatant liquid was discarded. The protein was taken up in $20 \mathrm{ml}$. of distilled water and dialyzed for 6 hours against 600 $\mathrm{ml}$. of distilled water. A small amount of precipitate formed during the dialysis which was readily removed by centrifuge. Aliquots were withdrawn from the supernatant liquor and diluted for protein analysis.

Protein content was determined colorimetrically by the method of Sutherland et al. (28), using 30-percent bovine albumen ${ }^{8}$ for standards. A reasonably stable blue color is developed when protein is incubated in the presence of dilute alkaline copper sulfate solution and phenol reagent (Folin-Ciocalteau). Optical density is measured at $660 \mathrm{~m} \mu$. This method is admirably suited for small quantities of protein in the range of 0.025 to $0.50 \mathrm{mg}$.

${ }^{8}$ Supplied by the Nutritional Biochemicals Corp., Cleveland 28, Ohio. 
Previous work with sugarcane-leaf extracts (1) revealed the presence of numerous enzymes commonly associated with the glycolytic and TCA or Krebs pathways, in addition to several other systems less intimately related to sugar metabolism. The following enzymes were measured during the present study: Amylase, maltase, invertase, hexokinase, acid phosphatases, glucose oxidase, phosphohexose isomerase, aldolase, phosphoglyceryl kinase, succinic acid dehydrogenase, transaminase, peroxidase, catalase, polyphenol oxidase, and $l$-amino acid oxidase. The acid phosphatases included $\beta$-glycerophosphatase, ATP-ase, 3-phosphoglyceric phosphatase, glucose-1-phosphatase, glucose-6-phosphatase, fructose-6-phosphatase, and fructose-1,6-diphosphatase. With the exception of maltase, glucose oxidase, and $l$-amino acid oxidase, the assay procedures employed during these experiments have been previously described in detail (1).

Maltase was measured by following the change of optical rotation it caused in a solution of maltose. All maltase assays were conducted with a Rudolf model No. 62 polarimeter equipped with a fixed half-shade polarizer prism of $7^{\circ}$ to $10^{\circ}$ half-shade angle, and employing a purified sodium light source for the $5893 \mathrm{~A}^{\circ}$ sodium line. The maltase reaction mixture was composed of $5 \mathrm{ml}$. of buffer-substrate solution (10-percent maltose in acetate buffer, $\mathrm{pH} 4.63), 0.5 \mathrm{ml}$. of distilled water, and $0.5 \mathrm{ml}$. of enzyme preparation. The reaction proceeded for 3 minutes at $22^{\circ} \mathrm{C}$. in a $50 \times 11.5-$ $\mathrm{mm}$. polarimeter tube. Controls received $0.5 \mathrm{ml}$. of enzyme preparation which had previously been heated to $100^{\circ} \mathrm{C}$. for 5 minutes. With the aid of the observed rotation values obtained after a 3 -minute reaction period, specific rotation of the reaction mixture was calculated by the following equation:

$$
\text { Specific rotation }=\frac{\text { Observed rotation in degrees }}{\text { Length of tube }(\mathrm{dm} .) \times \text { concentration }(\mathrm{gm} . / \mathrm{cc} .)}
$$

One maltase activity unit was defined as the amount of enzyme catalyzing the hydrolysis of $5 \mathrm{mg}$. of maltose in 3 minutes under the specified conditions of the assay.

Glucose oxidase and $l$-amino acid oxidase were measured manometrically with Warburg constant-volume manometers equipped with single sidearm reaction vessels. Manometers and vessels had been calibrated separately with mercury, by the technique of Santiago Grisolia, as described by Umbreit, et al. (28). Both enzymes were assayed by determining the extent of oxygen consumption during their respective reactions. For glucose oxidase, the main compartment of each vessel received $1 \mathrm{ml}$. of phosphate buffer ( $\mathrm{pH} 7.5$ ), $0.5 \mathrm{ml}$. of $2 \times 10^{-4}$ molar $\mathrm{DPN}^{9}, 0.25 \mathrm{ml}$. of

9 The glucose oxidase encountered in our enzyme preparations appears to be a true dehydrogenase, since its activity was virtually undetectable in the absence of DPN. 
enzyme preparation (representing 0.2 to $0.3 \mathrm{mg}$. of protein), and $0.25 \mathrm{ml}$. of $2 \mathrm{~N} \mathrm{NaOH}$ was placed in the center well. The sidearms of treatment vessels received $1 \mathrm{ml}$. of $0.2 \mathrm{M} d$-glucose, while controls received distilled water in place of glucose. The vessels and their contents were equilibrated for 3 minutes at $30^{\circ} \mathrm{C}$. in the instrument's constant-temperature waterbath. The manometers were tipped so that the glucose solutions entered the main compartment, and the enzyme reaction was subsequently run for 20 minutes. Microliters of oxygen consumed by the reaction were calculated with the aid of previously determined $\mathrm{KO}_{2}$ values. One glucose oxidaseactivity unit was defined as the amount of enzyme catalyzing the consumption of $1 \mu \mathrm{l}$. of oxygen under the specified conditions of the assay. The method for $l$-amino acid oxidase was identical with that of glucose oxidase, with the exceptions that $0.1 \mathrm{M} d l$-phenylalanine was employed as substrate, distilled water was substituted for DPN solution, and the reaction period was 10 minutes rather than 20 .

All data collected during this study were subjected to statistical analysis of variance and mean variations were compared by the Student-NewmanKeuls $Q$ test. Unless otherwise indicated, all results discussed hereafter are based upon variations found to be significant at the 5 or 1 percent level (table 1).

\section{RESULTS AND DISCUSSION}

The extent to which residual Diuron had altered the sugar-producing capability of the ratoon sugarcane remains highly debatable. Leaf sucrose was markedly suppressed (table 2), with the Diuron effect becoming progressively severe as increasing concentrations of Diuron were applied to the soil. Glucose was apparently caused to accumulate in the leaves by the high Diuron treatment, although our statistics did not verify the effect. On the other hand, the suppressing effects of the herbicide on percentage sucrose of juice and cane was relatively slight.

There can be no question, however, that residual Diuron was exerting strong effects upon a number of critical enzyme systems. The essential enzymes most strongly affected include the phosphate-transferring system hexokinase, and the phosphatases which hydrolyze the glucose and fructose phosphates needed for sucrose biosynthesis (table 1). Other important systems affected by Diuron include glucose oxidase, maltase, catalase, transaminase, and $l$-amino acid oxidase. The effects of Diuron upon these enzymes and the possible consequences of their altered action will be discussed in detail.

\section{HEXOKINASE AND THE HEXOSE PHOSPHATASES}

The 4- and 8-pound-per-acre Diuron treatments suppressed hexokinase to approximately one-third of control levels (table 3 , item 11). This effect 
was significant at the 1-percent level for both treatments (table 1, item 5). The hexokinase reaction may be written as follows:

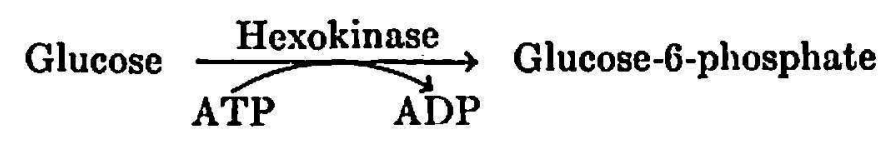

TABLE 1.-Summary of significant mean differences for leaf-sugar content and specific activity of leaf enzymes from ratoon sugarcane grown on soil treated 25 months previously with different quantities of Diuron ${ }^{1}$

\begin{tabular}{|c|c|c|c|c|c|}
\hline \multirow{2}{*}{ Item No. } & \multirow{2}{*}{ Data classification } & \multicolumn{4}{|c|}{ Diuron (pounds per acre) } \\
\hline & & 0 (control) & 2 & 4 & 8 \\
\hline 1 & Total ketoses & $0>8^{*}$ & $2>8^{*}$ & $4>8^{*}$ & \\
\hline 2 & Sucrose & $\begin{array}{l}0>2^{*} \\
0>8^{* *}\end{array}$ & $\begin{array}{l}2>4^{*} \\
2>8^{* *}\end{array}$ & $4>8^{*}$ & \\
\hline 3 & Glucose-6-phosphatase & $0>8^{* *}$ & $2>8^{* *}$ & $4>8^{*}$ & \\
\hline 4 & $\begin{array}{l}\text { Fructose-6-phospha- } \\
\text { tase }\end{array}$ & & & $\begin{array}{l}4>2^{* *} \\
4>0^{* *}\end{array}$ & $\begin{array}{l}8>2^{* *} \\
8>0^{* *}\end{array}$ \\
\hline 5 & Hexokinase & $\begin{array}{l}0>4^{* *} \\
0>8^{* *}\end{array}$ & $\begin{array}{l}2>4^{* *} \\
2>8^{* *}\end{array}$ & & \\
\hline 6 & Transaminuse & & $2>0$ & $\begin{array}{l}4>8^{* *} \\
4>2^{* *} \\
4>0^{* *}\end{array}$ & \\
\hline 7 & l-amino acid oxidase & & $\begin{array}{l}2>0^{*} \\
2>8^{* *}\end{array}$ & $4>8^{*}$ & \\
\hline 8 & Maltase & & & & $\begin{array}{l}8>0^{*} \\
8>4^{*} \\
8>2^{* *}\end{array}$ \\
\hline 9 & Glucose oxiduse & $0>8^{* *}$ & & $4>8^{*}$ & \\
\hline 10 & Catalase & $0>8^{* *}$ & $2>8^{* *}$ & & \\
\hline
\end{tabular}

1 The notations $0,2,4$, and 8 refer to data means from the Diuron treatments of $0,2,4$, and $8 \mathrm{lb}$. per acre, respectively. The symbol $(>)$ between 2 figures signifies chat the first treatment mean was greater than the second. One asterisk indicates significance at the 5-percent level, and 2 asterisks at the 1-percent level.

Hexokinase owes its critical nature to the fact that it catalyzes the partial degradation of essential ATP reserves, and its product, glucose-6-phosphate, occupies a key position in the pathways of hexose degradation and in the pathways leading to starch and sucrose biosynthesis. A close examination of the glycolytic pathway, such as that presented by Neilands and Stumpf $(17$, p. 248), shows that glucokinase represents one of the two systems whereby hexose may become phosphorylated from ATP prior to its glycolytic metabolism. Fructokinase represents the second system, but in its absence, as may well be the case for sugarcane ${ }^{10}$, glucokinase assumes

10 Earlier studies at this laboratory indicated that glucose may be the only direct hexose acceptor of phosphate from ATP in sugarcane leaves (1). 
even greater importance as the sole mechanism for the transfer of phosphate from ATP to hexose. Without a nonlimiting supply of glucose6-phosphate, the normal course of glycolysis, with its corresponding production of ATP-and Krebs-cycle precursors, could not be realized. Furthermore, in the event that the Embden-Meyerhof pathway should become blocked or curtailed, then glucose-6-phosphate would be required as the point of departure for the hexose monophosphate shunt $(11$, p. 279).

TABIE 2.-Mean values for sheath and leaf sugars, leaf protein, percentage sucrose of juice, and sucrose of cane from ratoon sugarcane grown on soils treated 25 months previously with different quantities of Diuron ${ }^{1}$

\begin{tabular}{|c|c|c|c|c|c|}
\hline \multirow{2}{*}{ Constituent (dry-wcight basis) } & \multicolumn{4}{|c|}{ Diuron (pounds per acre) } & \multirow{2}{*}{ Diuron mean } \\
\hline & Control & 2 & 4 & 8 & \\
\hline Sheath sugars..........mg./gm. & & & & & \\
\hline Total ketoses & 50.2 & 46.9 & 44.2 & 49.4 & 46.8 \\
\hline Sucrose & 24.9 & 23.5 & 21.2 & 25.0 & 23.2 \\
\hline Fructose & 25.3 & 23.6 & 22.9 & 24.4 & 23.6 \\
\hline Total reducing & 30.6 & 30.6 & 29.1 & 31.7 & 30.5 \\
\hline Glucose & 5.3 & 7.1 & 6.2 & 7.4 & 6.9 \\
\hline \multicolumn{6}{|l|}{ Leaf sugars . . . . . . . . . .mg./gm. } \\
\hline Total ketoses & 46.1 & 45.9 & 44.8 & 40.2 & 43.3 \\
\hline Sucrose & 21.7 & 21.2 & 18.0 & 15.5 & 18.2 \\
\hline Fructose & 24.3 & 24.7 & 26.8 & 23.0 & 24.8 \\
\hline Total reducing & 28.2 & 25.9 & 31.1 & 30.3 & 29.1 \\
\hline Glucose & 3.9 & 2.1 & 4.3 & 7.3 & 4.6 \\
\hline Leaf protein. . . . . . . . . . $\mu \mathrm{g} . / \mathrm{gm}$. & 318.0 & 343.0 & 327.0 & 405.0 & 358.0 \\
\hline Sucrose in juice.......... percent & 7.42 & 7.20 & 6.66 & 6.57 & 6.81 \\
\hline Sucrose in cane.......... percent & 5.21 & 4.96 & 4.73 & 4.65 & 4.78 \\
\hline
\end{tabular}

1 Each figure represents the computed mean of 6 replicates.

Taking into account the pathways leading to polysaccharide formation we find that glucose-6-phosphate lies but one enzymatic step away from glucose-1-phosphate, the direct precursor of starch. The enzyme phosphoglucomutase catalyzes the following reversible reaction, in which glucose6-phosphate may be converted to glucose-1-phosphate (17, p. 248):

$$
\text { Glucose-6-phosphate } \begin{gathered}
\stackrel{\text { Phosphoglucomutase }}{\mathrm{Mg}^{++}} \text {Glucose-1-phosphate } \\
+ \\
\text { Glucose-1, 6-diphosphate }
\end{gathered}
$$

The starch phosphorylase enzyme, found in potato tissues by Hanes (10), 
catalyzes a reversible reaction in which glucose-1-phosphate is employed in the formation of starch:

$$
\text { Glucose-1-phosphate } \stackrel{\text { Starch phosphorylase }}{\rightleftharpoons} \text { Starch }+\mathrm{H}_{3} \mathrm{PO}_{4}
$$

TABLE 3.-Mean specific-activity values for leaf enzymes of ratoon sugarcane grown on soils treated 25 months previously with different quantities of Diuron

\begin{tabular}{|c|c|c|c|c|c|c|}
\hline \multirow{2}{*}{ Item No. } & \multirow{2}{*}{ Enzyme } & \multicolumn{4}{|c|}{ Diuron (pounds per acre) } & \multirow{2}{*}{ Diuron mean } \\
\hline & & Control & 2 & 4 & 8 & \\
\hline 1 & $\beta$-glycerophosphatase & 8.3 & 8.2 & 8.4 & 6.0 & 7.5 \\
\hline 2 & ATP-ase & 0.6 & 7.0 & 8.4 & 5.2 & 6.9 \\
\hline 3 & 3-PGA phosphatase & 9.9 & 10.5 & 10.6 & 7.6 & 9.6 \\
\hline 4 & Glucose-1-phosphatase & 2.7 & 2.7 & 2.9 & 2.3 & 2.6 \\
\hline 5 & Glucose-6-phosphatase & 4.2 & 4.8 & 3.4 & 2.1 & 3.4 \\
\hline 6 & $\begin{array}{l}\text { Fructose-6-phospha- } \\
\text { tase }\end{array}$ & 2.0 & 2.0 & 7.1 & 5.6 & 4.9 \\
\hline 7 & $\begin{array}{l}\text { Fructose-1,6-diphos- } \\
\text { phatase }\end{array}$ & 6.4 & 6.6 & 6.2 & 5.4 & 6.1 \\
\hline 8 & Peroxidase & 7.1 & 9.1 & 9.8 & 8.2 & 9.0 \\
\hline 9 & Polyphenol oxidase & 2.2 & 2.0 & 2.1 & 1.8 & 2.0 \\
\hline 10 & $\begin{array}{l}\text { Isocitric acid dehydro- } \\
\text { genase }\end{array}$ & 7.9 & 7.2 & 7.4 & 5.8 & 6.8 \\
\hline 11 & Hexokinase & 8.8 & 8.9 & 2.8 & 2.5 & 4.7 \\
\hline 12 & Amylase & 39.0 & 30.4 & 34.1 & 23.8 & 29.4 \\
\hline 13 & Invertase & 3.2 & 3.0 & 3.1 & 2.8 & 3.0 \\
\hline 14 & Aldolase & 16.3 & 13.2 & 17.4 & 15.8 & 15.5 \\
\hline 15 & $\begin{array}{l}\text { Phosphohexose iso- } \\
\text { merase }\end{array}$ & 7.0 & 14.3 & 8.2 & 11.0 & 11.2 \\
\hline 16 & $\begin{array}{l}\text { Phosphoglyceryl ki- } \\
\text { nase }\end{array}$ & 2.2 & 1.2 & 2.0 & 1.6 & 1.6 \\
\hline 17 & Transaminase & 11.2 & 12.3 & 17.6 & 13.7 & 14.5 \\
\hline 18 & $l$-amino acid oxidase & 10.2 & 12.9 & 13.1 & 8.8 & 11.6 \\
\hline 19 & Catalase & 16.2 & 13.5 & 12.3 & 8.8 & 11.5 \\
\hline 20 & Glucose oxidase & 7.7 & 5.7 & 6.2 & 3.8 & 5.2 \\
\hline 21 & Maltase & 3.6 & 1.9 & 3.5 & 6.1 & 3.8 \\
\hline
\end{tabular}

1 Each figure represents the computed mean of 6 replicates.

The energy needed for the synthesis of the hexose-hexose bond comes from the energy of the phosphate linkage of glucose-1-phosphate, and is derived from the original phosphorylation of glucose $(3$, p. 60). The curtailment of hexokinase by Diuron could thus indirectly affect the net increase of starch by limiting the initial phosphorylation of free glucose from ATP.

In like manner a suppressed hexokinase reaction might also affect sucrose synthesis by indirectly limiting the supply of glucose-1-phosphate. The 
sucrose phosphorylase reaction discussed by Bonner $(3$, p. 40$)$ employs glucose-1-phosphate in the formation of the glycosidic bond of sucrose:

$$
\text { Glucose-1-phosphate }+ \text { fructose } \stackrel{\text { Sucrose phosphorylase }}{\rightleftharpoons} \text { Sucrose }+\mathrm{H}_{3} \mathrm{PO} \text {, }
$$

The energy required for the glycosidic-bond formation is likewise derived from the original phosphorylation of glucose. It is evident, therefore, that in addition to affecting the flow of hexose into the glycolytic pathway, the suppression of hexokinase by Diuron might affect the synthesis of both starch and sucrose.

Further significance of the Diuron effects upon hexokinase and the hexose phosphatases becomes evident in the light of the sucrose biosynthesis reactions developed by Leloir and coworkers $(4,15,18)$. These investigators have brought forward the following series of reactions involving both glucose-1-phosphate and fructose-6-phosphate:

1. Uridine triphosphate (UTP) + glucose-1-phosphate $\rightarrow$

Uridine diphosphate glucose (UDPG) + pyrophosphate (PP)

2. A, UDPG + fructose $\rightarrow$ Sucrose + uridine diphosphate (UDP)

B, UDPG + fructose-6-phosphate (F-6-P) $\rightarrow$ Sucrose phosphate + UDP

In addition to the phosphoglucomutase reaction mentioned above, another enzyme common to plant tissues, phosphohexose isomerase, can convert glucose-6-phosphate to a form which may enter directly into the sucrose biosynthesis reactions:

Glucose-6-phosphate $\stackrel{\text { Phosphohexose isomerase }}{\rightleftharpoons}$ Fructose-6-phosphate

(70 percent)

(30 percent)

The product fructose-6-phosphate may enter reaction 2-B.

It is at once evident that a series of phosphatases capable of rapidly hydrolyzing the glucose and fructose phosphates could inhibit sucrose production through depletion of the essential phosphorylated metabolites. It is interesting to note that the Diuron treatment of 8 pounds per acre, which curtailed leaf sucrose, suppressed glucose-6-phosphatase (tables 1 and 3) and failed to affect glucose-1-phosphatase. This response in itself should have been favorable to sucrose biosynthesis. On the other hand, fructose-6-phosphatase was strongly stimulated by Diuron (table 3, item 6) among the 4- and 8-pound-per-acre treatments. This leads us to suspect that fructose-6-phosphate was a critical intermediary for sucrose synthesis, and its depletion as a result of the Diuron treatment constitutes a Diuronphosphatase relationship which is perhaps equally as significant as the Diuron suppression of hexokinase.

Before leaving the subject of hexokinase and the sugar phosphatases it 
is well to mention again the work of Tomizawa (26) who found that, while Monuron increased the uptake of $\mathrm{P}^{32}$ by soybean, the incorporation of inorganic phosphorus into metabolic intermediates such as 3-phosphoglyceric acid, glucose-1-phosphate, and hexose diphosphate was decreased. It was suggested that this resulted from inhibition of photosynthesis, but a similar effect would be rendered by the Diuron suppression of hexokinase and stimulation of phosphatase observed during our own studies.

\section{GLUCOSE OXIDASE AND CATALASE}

Up to this point we have discussed the effects and possible consequences of Diuron upon the phosphorylated hexose content of sugarcane leaves, but it is also apparent that the herbicide may have been influencing the levels of free glucose via the enzyme glucose oxidase. This system was suppressed by 8 pounds of Diuron to less than half of the control levels (table 3, item 20), and the statistical analyses indicate that the effect was significant at the 1-percent level (table 1, item 9).

Sumner and Somers (25, p. 292) describe the following reaction in which oxygen is consumed and hydrogen peroxide is liberated during the enzymecatalyzed oxidation of $d$-glucose:

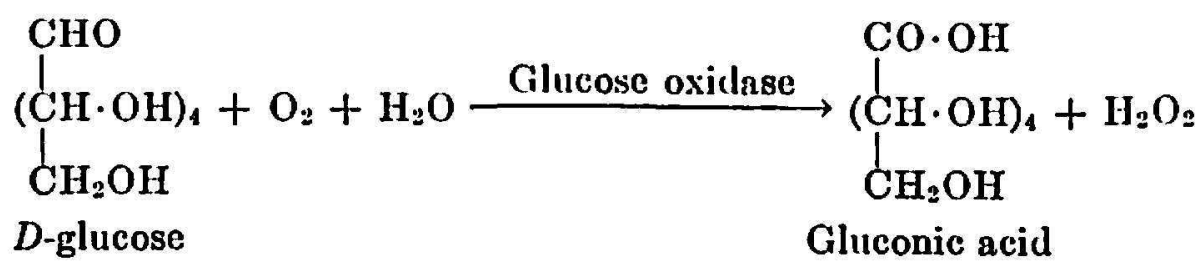

It may be noted that during the formation of gluconic acid, $d$-glucose is oxidized at the aldehydic end of the molecule and does not experience the degradation to 3-carbon units, and subsequently to $\mathrm{CO}_{2}$ and water, which is the fate of hexoses passing through the respiratory pathways. However, glucose is effectively removed from physiological reactions subsequent to and including phosphorylation by ATP and hexokinase.

Glucose oxidase is one of the "yellow enzymes" containing two molecules of FAD per molecule of enzyme (6). Recalling the work of Todd and coworkers (7), which revealed a protective action of FMN against Monuron through the formation of a nonlethal complex of FMN with Monuron, it is tempting to speculate that Diuron may have suppressed glucose oxidase by reacting with one or both of the enzyme's FAD molecules. There are certain similarities in the structural components and configurations of Diuron and FAD, so that the enzyme may have "mistaken" Diuron for its true prosthetic group.

Whistler et al. (31) describe glucose oxidase as a true dehydrogenase, and 
propose that the enzyme is one of three essential systems catalyzing the following sequence of reactions:

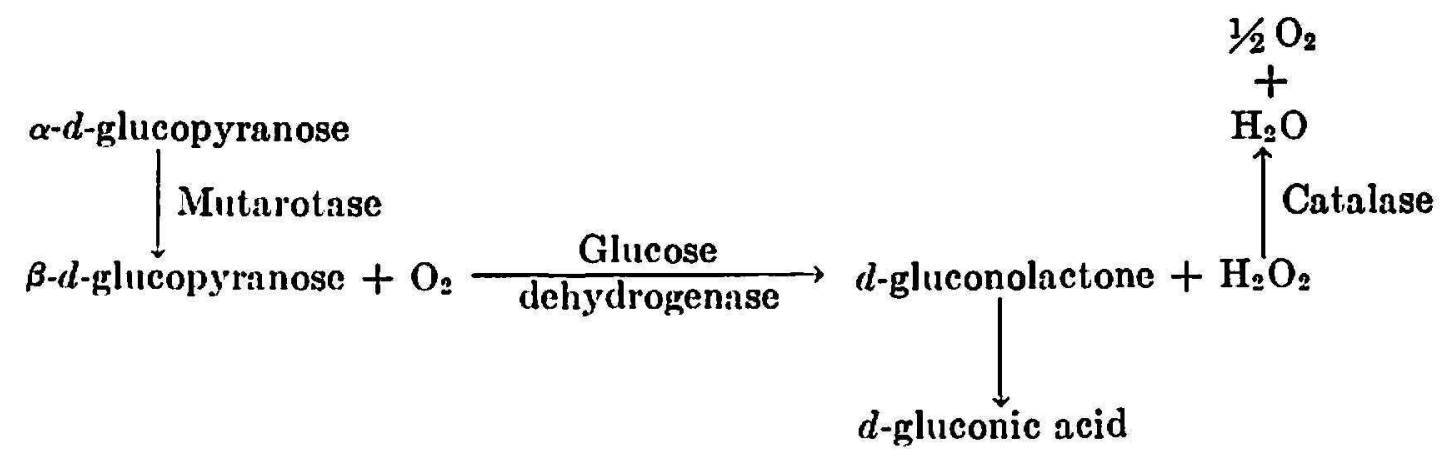

Our own enzyme preparations appeared to catalyze reactions of the above sequence, since maximum glucose oxidase required added DPN, and because a close similarity exists between the responses of both glucose oxidase and catalase to Diuron. Both enzymes were markedly suppressed by the 8pound-per-acre treatment (table 3, items 19 and 20). In the above series of reactions a significant decrease in either catalase or glucose oxidase should be accompanied by a corresponding decrease in the other enzyme.

\section{MALTASE VS. STARCH METABOLISM}

Previous work revealed the presence of an extremely powerful amylase system in cane-leaf extracts (1), and it was difficult to comprehend the physiological role of the apparently excessive action. During the study amylase was suppressed by the low nitrate treatments which, in turn, increased leaf sucrose. We suggested that starch may serve as a source of glucose for sucrose synthesis, which would explain the need for amylase, but the connection between amylase suppression and increased sucrose, as a result of low nitrate, continued to elude us. The present study included the enzyme maltase, in addition to amylase, and the stimulation of maltase hy Diuron has given us enough evidence to form a hypothesis which may account for the sucrose-starch relationship in cane.

It was pointed out in earlier paper (1) that, even when greatly suppressed by low nitrate, the amylase of cane leaves was still able to produce far more maltose, and consequently a source of glucose via maltase action, than could logically be required by the plant for sucrose synthesis. However, from the standpoint of latent energy expended, this action of amylase might have serious consequences for sucrose production and many other physiological processes. Starch consists of glucopyranose residues linked together through $1,4 \beta$-glucosidic linkages $(3$, p. 53$)$. The synthesis of these linkages by starch phosphorylase from glucose-1-phosphate is dependent upon energy originally derived through the phosphorylation of free glucose. So long as the starch glucosidic linkages are broken by the reverse starch phosphorylase 
reaction, the energy held by these linkages will be retained in the glucose-1phosphate bond ${ }^{11}$.

However, when these linkages are broken by amlyase there is no provision for trapping the free energy of hydrolysis and this is subsequently lost to the system as heat energy. With this concept in mind it is now evident that excessive amylase action, regardless of the quantity of potential glucose released, will provide a drain upon the plant's latent energy which has been passed from ATP to glucose to the 1,4 glucosidic linkages of starch. It is even possible that in plant tissues where no appreciable starch reserves have accumulated, excessive amylase could rapidly hydrolyze starch as soon as it is formed and thus shift the hexokinase-phosphoglucomutase-starch phosphorylase sequence far enough to the right seriously to deplete ATP reserves. On this basis we hypothesize that the relationship between suppressed amylase and increased sucrose synthesis was realized through an improved conservation of energy reserves ${ }^{12}$.

During the present study it was observed that maltase was one of the few enzymes progressively stimulated by increasing concentrations of Diuron (table 3, item 21). The comparatively high maltase activity from leaf samples in which sucrose content was low led to a reconsideration of the role of the starch degradating systems. Amylase was not significantly affected by Diuron, but nevertheless a high maltase activity would be one of the component features of a starch-metabolizing sequence capable of depleting energy reserves needed for sucrose biosynthesis.

\section{TRANSAMINASE AND $l$-AMINO ACID OXIDASE}

Variable Diuron treatments significantly affected the activity of transaminase and $l$-amino acid oxidase, but the meaning of these responses is difficult to define. Transaminase was measured by the method of Tonhazy et al. (27), and is based upon the transfer of the amino group of $l$-aspartic acid to $\alpha$-ketoglutaric acid, or, in other words, involves the formation of an amino acid from a nonamino organic acid. $\alpha$-Ketoglutaric is one of the commonly occurring organic acids of the TCA or Krebs cycle, and is derived through the metabolism of carbohydrates. The transaminase reaction can

11 The breakdown of starch by the starch phosphorylase reaction does not represent simple hydrolysis $(s$, p. 60$)$ as would be the case for amylase, but rather it is a phosphorolysis in which the elements of phosphoric acid are added to each broken hexose-hexose bond. The energy conserved by the glucose-1-phosphate bond may later be transfered to the adenylic acid system as the hexose phosphate is metabolized through the appropriate stages of glycolysis $(17$, p. 255).

12 It is perhaps significant that the low-nitrate treatments which suppressed amylase also suppressed the ATP-ase system (1), thus further promoting a more satisfactory ATP status under conditions of low nitrate. 
therefore be regarded as an important link between the processes of carbohydrate degradation and those of protein synthesis. This being the case we might have expected to find a relatively high leaf-protein content associated with the 4-pound-per-acre treatment which stimulated transaminase. Actually there was a slight protein increase at the 8-pound level (table 2) rather than at the 4-pound, and even this was not statistically significant.

The action of $l$-amino acid oxidase was suppressed by 8 pounds of Diuron, as compared to the 4- and 2-pound treatments (table 1, item 7). Apparently an indefinite group of $l$-amino acid oxidases occur in biological material which destroy the natural or $l$-amino acids by catalyzing their oxidative deamination (25, p. 287-292). The ultimate products of this reaction are the free keto acid, ammonia, and water:

$$
\mathrm{R} \cdot \mathrm{CHNH}_{2} \cdot \mathrm{COOH}+1 / 2 \mathrm{O}_{2} \rightarrow \mathrm{R} \cdot \mathrm{CO} \cdot \mathrm{COOH}+\mathrm{NH}_{3}+\mathrm{H}_{2} \mathrm{O}^{13}
$$

Since $l$-amino acid oxidase destroys the building units needed for protein synthesis, the suppression of this system should favor a greater protein content, which may explain the slight increase of protein among the 8-pound Diuron treatment.

Amino acid oxidases whose chemical nature has been studied in detail have been found to be flavoproteins $(21,22)$. Possibly the suppressing effect of Diuron upon the sugarcane enzyme was effected through the formation of a flavin-herbicide complex, in the nature of that described by Todd and coworkers (7), or through the substitution of Diuron for the true flavin prosthetic group.

In all probability some relationship exists between the Diuron-induced suppression of leaf sucrose and the formation of leaf protein. Transaminase and $l$-amino acid oxidase must take part in the protein synthesis phase, but as of this moment we have insufficient information to place together a cohesive hypothesis.

\section{SUMMARY OF DIURON-ENZYME RELATIONSHIPS}

The following diagram is presented to summarize the Diuron-enzyme relationships thus far discussed, and, in particular, to illustrate the pathways upon which Diuron may have affected the synthesis of sucrose and starch. Encircled numbers refer to enzymes found to be altered by Diuron ${ }^{14}$.

1s The fact that these reactions are not balanced is accounted for by the assumption that, initially, an amino acid is formed, and that this is later hydrolyzed to the keto acid and ammonia.

${ }_{14}$ Legend: 1, Hexokinase; 2, glucose-6-phosphatase; 3, fructose-6-phosphatase; 4 , glucose oxidase; 5 , maltase; 6 , catalase; $7, l$-amino acid oxidase; 8 , transaminase. 


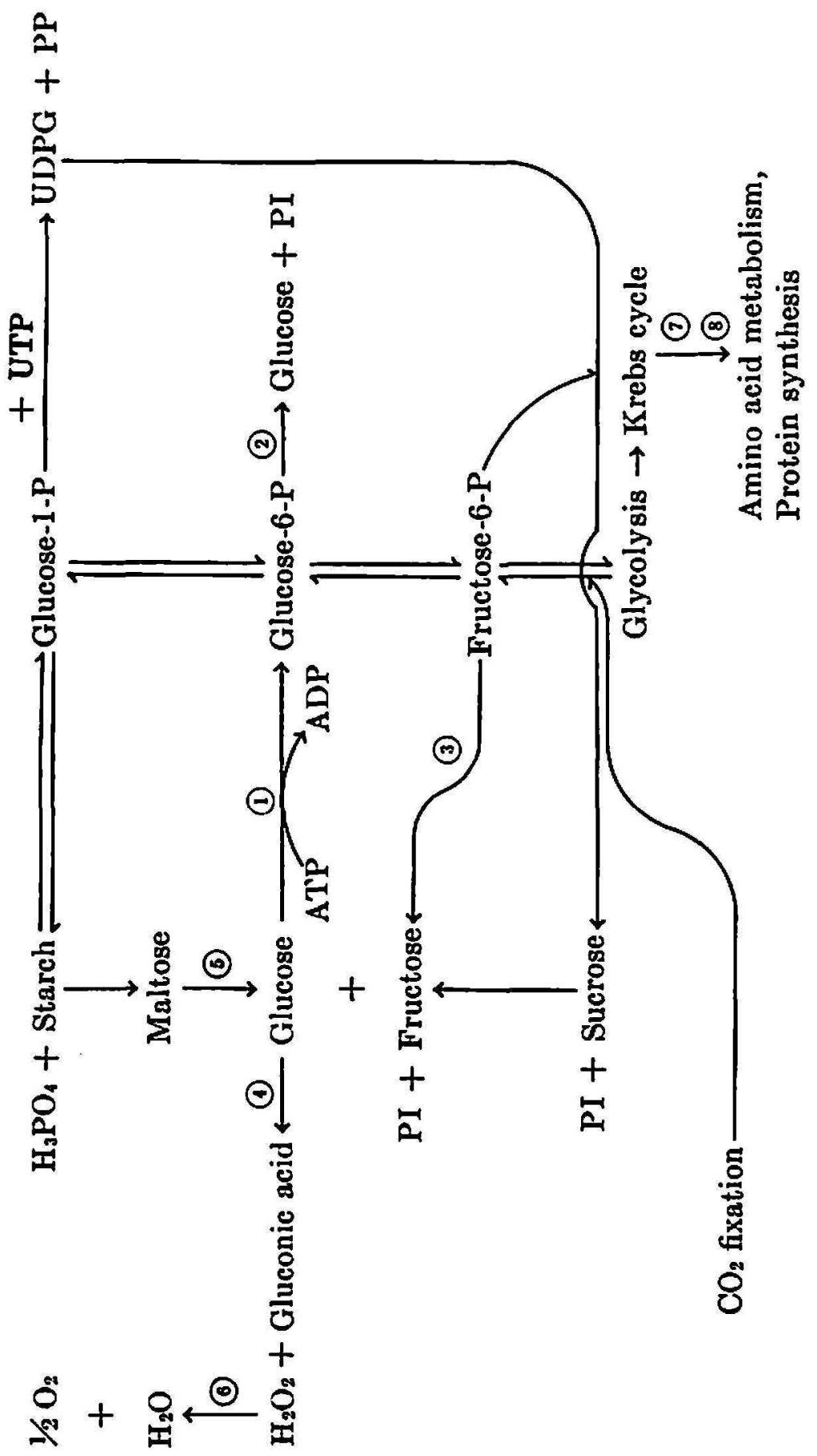

Examination of the above diagram reveals four hypothetical pathways by which a net increase of sucrose may be realized in sugarcane leaves:

1: Starch $\rightarrow$ G-1-P $\stackrel{+ \text { UTP }}{\longrightarrow}$ UDPG $\stackrel{+ \text { F-6-P (via isomerase) }}{\longrightarrow}$ Sucrose

2: Starch $\rightarrow$ Maltose $\rightarrow$ Glucose $\rightarrow$ G-6-P $\rightarrow$ G-1-P $\stackrel{+ \text { UTP }}{\longrightarrow}$

$$
\mathrm{UDPG} \stackrel{+\mathrm{F}-6-\mathrm{P}}{\longrightarrow} \text { Sucrose }
$$


3: $\mathrm{CO}_{2}$ Fixation $\rightarrow$ F-6-P

Each pathway involves at least one enzyme affected by Diuron, and at least two enzymes in each of the first three pathways.

The key positions of both free glucose and glucose-6-phosphate are at once evident. Only via pathway No. 4 could sucrose be produced without involving free glucose or the phosphate ester.

From the standpoint of energy conservation, not all of the above pathways are equally advantageous to the plant. Using the metabolism of glucose in animal tissues as a model $(1 \%$, p. 256) we know that a net synthesis of two high-energy $(\sim)$ bonds is realized during the complete metabolism of one molecule of glucose. When glycogen is utilized instead of glucose (starch in plants), three high-energy $(\sim)$ bonds are realized since the initial hexose phosphate (glucose-1-phosphate) is derived by phosphorolysis rather than through the conversion of ATP to ADP. The supply of ATP available to the plant would thus depend greatly upon the source of hexose involved in glycolysis. The same principle applies to the sucrose-synthesis reactions. By pathway No. 4, for example, sucrose would be formed without utilizing any more ATP than was required for the phosphorylation of the original $\mathrm{CO}_{2}$ fixation intermediates ${ }^{15}$.

Pathway No. 2, on the other hand, would involve the loss of the energy held in the 1,4 glucosidic linkages of starch (as heat energy via the amylasemaltase sequence), and would also involve the utilization of one ATP molecule for every glucose molecule phosphorylated via the hexokinase reaction. Pathway No. 1 may or may not represent an extra expenditure of energy, depending upon whether starch was originally degradated by amylase-maltase or the starch phosphorylase system to form the precursor of fructose-6-phosphate. Pathway No. 3 would bypass the amylase-maltasehexokinase pathway but would require one additional enzymatic reaction, over pathway No. 4, during the conversion of fructose-6-phosphate to glucose-1-phosphate. Therefore pathway No. 4 would seem to be the most logical, if energy conservation is a matter of importance to the plant.

The information we have gathered from the Diuron studies does not tell us specifically which of the hypothetical sucrose-forming sequences might have been curtailed by the high-Diuron treatment. The marked stimulation

${ }^{16}$ A total of 9 ATP molecules are converted to ADP during a single complete turn of the carbon-reduction cycle. However, insofar as the above pathways 3 and 4 are concerned, this does not represent additional energy expenditure over pathways 1 and 2 , because the original synthesis of starch utilized the hexose products of $\mathrm{CO}_{2}$ fixation. 
of fructose-6-phosphatase could have implicated all four. But evidence from this and earlier studies strongly suggests that pathway No. 2 is dominant in sugarcane. The evidence may be summarized as follows:

1. Maximum sucrose production has been found associated with the same treatment which suppressed amylase ${ }^{16}$, ATP-ase, glucose-6-phosphatase, and glucose-1-phosphatase (1).

2. Minimum sucrose production has been found associated with the same treatment which stimulated maltase, suppressed glucose oxidase, suppressed hexokinase, and stimulated fructose-6-phosphatase (present study).

The above evidence also suggests that sucrose synthesis in cane includes hexose which has already passed from the $\mathrm{CO}_{2}$ fixation pathways into polysaccharide or storage form. Otherwise the amylase, maltase, glucose oxidase, and hexokinase systems need not have had any relationships with the sucrose-affecting treatments.

\section{THE SUGAR ACCUMULATION CYCLE}

No definite answer can be given to account for the differing Diuron effects upon sucrose content of leaves and canes. The work of Sacher et al. (20) provides the best explanation available at the moment. These investigators propose that sugars pass through three distinct cell compartments when accumulating from a medium into storage tissue. These compartments are termed the "outer space", the "metabolic compartment", and the "storage compartment". The process by which sugars are actively moved to the storage compartment and subsequently lost by diffusion is termed the "sugar accumulation cycle". It is believed that sucrose does not pass directly from the medium to the storage compartment, but rather is temporarily inverted through the mediation of an acid invertase in the outer space. Sucrose later reappears in the storage compartment.

Applying this concept to our own studies we would obviously visualize all of the leaf sucrose as part of the initial sucrose fraction of the medium phase. It is possible that Diuron exerts some effect upon the active accumu-

${ }^{16}$ The suppression of amylase by low nitrate $(1)$ is presented as evidence, not in the sense that the enzyme is involved in the supply of glucose for sucrose synthesis, but in the sense that both a greater energy conservation and more a favorable Keq (toward glucose-1-phosphate) might well result from the less acid $\mathrm{pH}$ values anticipated under conditions of low nitrate, and which subsequently would shift the pHsensitive phosphorylase equilibrium to the right $(3, \mathrm{p} .61)$. In the test tube, all amylase reactions were run with buffered media, and, therefore, the favorable effects upon the phosphorylase Keq would be due solely to the lessened ability of amylase to maintain the components of starch in a solute rather than solid form. In other words, so long as amylase was not able to keep the starch totally hydrolyzed, some of the glucose would be bound in a solid form, as a constant, and thus would be removed from the Keq expression. 
lation of sucrose into (or diffusion from) the storage space, or upon enzymes directly or indirectly involved in catalyzing the necessary reactions of the cycle. The fate of sucrose after it has been synthesized in the leaves thus may be an essential factor requiring clarification before the pattern of Diuron-sucrose relationships will be complete.

\section{SUMMARY}

A series of sugar and enzyme analyses were conducted with 5- to 6-monthold ratoon sugarcane to study the residual effects of Diuron upon certain sugar metabolizing systems. The cane represented the first ratoon crop growing on a Mabi clay soil treated 25 months previously with the equivalent of 2,4 , and 8 pounds per acre of Diuron. Total leaf ketoses and sucrose were significantly suppressed by 4 and 8 pounds per acre Diuron. Sheath sugars and percentage of sucrose of the juice and cane were only slightly affected by the herbicide. The activity of a number of critical enzymes was significantly altered by Diuron. These included maltase, hexokinase, glucose-6-phosphatase, fructose-6-phosphatase, glucose oxidase, transaminase, $l$-amino acid oxidase, and catalase. The nature of these variations and their possible consequences to the cane physiology are discussed in detail.

\section{RESUMEN}

Se hizo una serie de análisis para azúcar y enzimas en caña de azúcar de retoño, de 5 a 6 meses de edad, para estudiar los efectos residuales del Diuron sobre ciertos sistemas metabolizadores del azúcar. La caña era de la primera cosecha de retoño sembrada en un suelo Mabí arcilloso, el cual se había tratado 25 meses antes con cantidades de Diuron equivalentes a 2, 4, y 8 libras por acre. Las ketosas y la sacarosa totales de la hoja desaparecieron significativamente con las aplicaciones de 4 y 8 libras de Diuron por acre. El yerbicida sólo afectó muy ligeramente los azúcares de la vaina de la hoja y el porcentaje de sacarosa en el jugo y en la caña. El Diuron alteró significativamente la actividad de un número de enzimas de máxima importancia. Estas incluían maltasa, hexokinasa, glucosa-6-fosfatasa fructosa-6-fosfatasa, glucosa oxidasa, transaminasa, $l$-amino ácido oxidasa y catalasa. Se discute detalladamente la naturaleza de estas variaciones y las consecuencias posibles que pueden resultar en cuanto a la fisiología de la caña de azúcar.

\section{LITERATURE CITED}

1. Alexander, A. G., Sucrose-enzyme relationships in immature sugarcane as affected by variable nitrate and potassium supplied in sand culture, J. Agr. Univ. P.R. 48 (3) $165-231,1964$. 
2. Bishop, N. I., Influence of the herbicide, DCMU, on the oxygen evolving system of photosynthesis, Biochem. et Biophys. Acta 27(1) 205-6, 1958.

3. Bonner, J., Plant Biochemistry, Academic Press Inc., Publishers, New York, N.Y., 1950.

4. Cardini, C. E., Leloir, L. F., and Chiriboga, J., The biosynthesis of sucrose, J. Biol. Chem. 214 149-55, 1955.

5. Cooke, A. R., A possible mechanism of action of the urea type herbicides, Weeds 4 (4) $397-8,1956$.

6. Coulthard, C. E., Michaelis, R., Short, W. F., Sykes, G., Skrimshire, G. E. H., Standfort, A. F. B., Birkinshaw, J. H., and Raistrick, H., Notatin: An antibacterial glucose-aerodehydrogenase from Penicillium notatum Westling and Penicillium resticulosum sp. nov., Biochem. J. 39 24-36, 1945.

7. Crafts, A. S., The Chemistry and Mode of Action of Herbicides, Interscience Publishers, New York, N.Y., 1961.

8. Geoghegan, M. J., The effect of some substituted methylureas on the respiration of Chlorella vulgaris var. viridus, New Phylol. 66 71-80, 1957.

9. Gentner, W. A., and Hilton, J. L., Weed Soc. Amer., 1960 meeting, abstracts, February, p. 32.

10. Hanes, C. S., Reversible formation of starch from glucose-1-phosphate catalyzed by potato phosphorylase, Proc. Roy, Soc. (London), B129 174-9, 1940.

11. Harrow, B., and Mazur, A., Textbook of Biochemistry, 8th ed., W. B. Saunders Co., Philadelphia, Pa., 1962.

12. Hilton, J. L., Effect of histidine on the inhibitory action of 3-amino-1,2,4triazole, Weeds 8(3) 392-6, 1960.

13. Jagendorf, A. T., The relationship between electron transport and phosphorylation in spinach chloroplasts, Brookhaven Symposium in Biology No. 11 236-58, 1958.

14. Kuijper, J., Archief. Suikerind. Ned. Indiee. 23 528-56, 1915.

15. Leloir, L. F., and Cardini, C. E., The biosynthesis of sucrose phosphate, J. Biol. Chem. 214 157-65, 1955.

10. Moreland, D. E., Hill, K. L., and Hilton, J. L., Interference with the photochemical activity of isolated chloroplasts by herbicidal materials, Weed Soc. Amer., 1958 meeting, abstracts, p. 40.

17. Neilands, J. B., and Stumpf, P. K., Outlines of Enzyme Chemistry, John Wiley \& Sons, Inc., 1955.

18. Paladini, A. C., and Leloir, L. F., Studies on uridine-diphosphate-glucose, Biochem. J. 51 426-30, 1952.

19. Roe, J. R., A colorimetric method for the determination of fructose in blood and urine, J. Biol. Chem. 107 15-22, 1934.

20. Sacher, J. A., Hatch, M. D., and Glasziou, K. T., Sugar accumulation cycle in sugar cane, III, Physical and metabolic aspects of cycle in immature storage tissues, Plant Physiol. 38(3) 348-54, May 1963.

21. Singer, T. P., and Kearney, E. B., The $l$-rmino acid oxidases of snake venom, II, Isolation and characterization of homogenous $l$-amino acid oxidase, Arch. Biochem. 29 190-209, 1950.

22. Straub, F. B., Coenzyme of the $d$-amino acid oxidase, Nature $141603-4,1938$.

23. Sutherland, E. W., Cori, C. F., Haynes, R., and Olsen, N. S., Purification of the hyperglycemic-glycogenolytic factor from iusulin and from Gastric Mucosa, J. Biol. Chem. 180 825-37, 1949.

24. Sumner, James B., Dinitrosalicylic acid: A reagent for the estimation of sugar in normal and diabetic urine, J. Biol. ('hem. $475-9,1921$. 
25. Sumner, James B., and Somers, G. F., Chemistry and Methods of Enzymes, 3d. ed., Academic Press, Inc., New York, N.Y., 1953.

26. Tomizawa, C., Effects of 2,4-dichlorophenoxyacetic acid (2,4-D) and 3-(pchlorophenyl)-1,1-dimethyl urea (CMU) on phosphorus metabolism in soybean plants, Tokio Natl. Inst. Agr. Sci. B. Sec. C., Phytopathl., Ent. 6 103, 1956.

27. Tonhazy, N. E., White, N. G., and Umbreit, W. W., A rapid method for the estimation of the glutamic-aspartic transaminases in tissues and its application to radiation sickness, Arch. Biochem. $2836-42,1950$.

28. Umbreit, W. W., Burris, R. H., and Stauffer, J. F., Manometric Techniques, 3d. ed., Burgess Publishing Co., Minneapolis, Minn., 1959.

29. Weed Control Handbook, E. K. Woodford, ed., Blackwell Scientific Publications, Oxford, England, 1960.

30. Wessels, J. S. C., and van der Veen, R., Action of some derivatives of phenylurethan and of 3-phenyl-1,1-dimethylurea on the Hill reaction, Biochem. et Biophys. Acla 19 548-9, 1956.

31. Whistler, M. E., Hough, L., and Hylin, J. W., Determination of $d$-glucose in corn syrups by use of glucose dehydrogenase, A nal. Chem. 25 1215-6, 1953. 